\title{
Public Spaces for Children in a Post-Socialist City
}

\author{
Milena Krklješ ${ }^{\star}$, Dejana Nedučin \\ University of Novi Sad, Faculty of Technical Sciences, Department of Architecture and Urban Planning, Novi Sad, Serbia
}

\begin{abstract}
Citation: Krklješ M, Nedučin D. Public Spaces for Children in a Post-Socialist City. SEE J Archit Des. 2016 Feb 24; 2016:10012

Key words: urban transtorion Key words: urban transformation; public spaces for children; playgrounds.

'Correspondence: Milena Krklješ. University of Novi Sad, Faculty of Technical Sciences, Department of Architecture and Urban Planning, Novi Sad, Serbia. E-mail
milenakrkljes@gmail.com

Received: 02-Jan-2016; Revised: 21-Feb-2016 Accepted: 22-Feb-2016; Published: 24-Feb-2016

Copyright: ๑ 2016 Milena Krklješ, Dejana Nedučin. This is an open-access article distributed under the terms of the Creative Commons Attribution License, which permits unrestricted use, distribution, and reproduction in any medium, provided the original author and source are
credited.

Competing Interests: The author have declared that no competing interests exis
\end{abstract}

\begin{abstract}
\end{abstract}
AIM: The aim of this research is to present the outcomes of urban transformations during the post-socialist period in Novi Sad, Serbia, from the aspect of quality of public spaces for children.

MATERIAL AND METHODS: This research is a contribution to the process of designing public spaces for children in the times of rapid urban changes and a step forward to creating adequate places for children's play.

RESULTS: The socialist legacy of architectural design and urban planning strategies in terms of housing was altered by the new post-socialist patterns. Residential construction became insufficiently regulated and predominantly profit-driven, which resulted in a disregard of the value public spaces for children should have.

CONCLUSIONS: Upon analysing public spaces for children in the city after transition, it can be concluded that there is a significant shortage of attractive places for gathering, play and other leisure activities in many of newly built urban neighbourhoods. It also seems that architects and urban planners did not pay much attention to children's needs. The distribution of public spaces, their proportions and dimensions, programs and contents, should all be planned with the aim to create harmony between spaces and their users, making the whole process of socialization more successful and intensive.

\section{Introduction}

Public spaces are important elements of urban texture that reflect the patterns of everyday urban life, thus defining its quality. The phrase public space stands for inbuilt places in the city, accessible to all different social groups of citizens. They are the places of meetings, events, exchange and many other aspects of social interaction. These spaces are valued upon their morphology, architectural and urban structure, various social, psychological and ambient characteristics, but also according to a criterion how suitable they are for children's play.

Substantial changes in the outlook of Serbian cities have occurred after the collapse of socialism. The shift in market forces led to the emergence of domestic entrepreneurs as the new actors in urban development [1], especially from the aspect of housing construction. The socialist model of housing construction and urban planning primarily relied on the centralized economic system and absence of land market that could thus be considered as "the most important features that have shaped a distinctive structure of socialist cities, significantly different from capitalist cities in Western Europe" [2]. The appearance of private investments at the turn of the centuries, right after the major economic crisis that Serbia was struck by, resulted with the shift from the traditional collective ownership over housing, typical for the socialist period, to the private one in an ad hoc manner. Private investors caused significant profitdriven alterations in existing urban fabric, resulting in an increase of both population and construction density that changed the quality of built environment. These new post-socialist practices have also influenced the alteration in design of public spaces, which are today seen as "a stage in the arena of urban life: the place of anarchy, conflicts and codex it has as its concrete result" [3]. In case of Serbian cities, the design process is frequently missing and public spaces for children, necessary for their proper 
psychophysical development, are often neglected. As a part of population that cannot materialise its needs and wishes independently, children are usually left to spend their time on undersized and poorly designed playgrounds.

This paper investigates the impact that postsocialist transformations of several residential neighbourhoods in Novi Sad, Serbia, had on the public spaces for children. It also explains direct and indirect causes of sudden alteration of housing typology and morphology of built environment, which generated new and different overall identity of public spaces.

The aim of this research is to present the outcomes of urban transformations during the postsocialist period in Novi Sad, Serbia, and to define recommendations how to make public spaces in transitional city more appropriate to children's needs.

\section{Transformation of public spaces residential neighbourhoods}

in

The socialist period in Novi Sad brought large housing estates with multi-storey buildings, inspired by the International Style, and an abundance of vast public spaces that were designed according to the principles of proper urban elements implementation and in accordance with children's needs. Even reallotment of spacious courtyards of existing singlefamily houses and insertion of free standing and slablike buildings in existing neighbourhoods during the 1960s have been carried out with the respect to the quality of public spaces. Within open spaces that were surrounding those buildings, green areas, sports grounds and children playgrounds were articulated. Since properly designed, those spaces are still in use, although a bit devastated (Figure 1).

Due to a major socio-economic crisis and state's withdrawal from funding in the beginning of 1990s, Novi Sad was faced with a short break in housing construction and it was difficult to predict that this branch would start blooming shortly after [5]. Housing construction became market-orientated and almost exclusively sponsored by private capital, which made the private sector a new actor and the main investor in urban development [4]. Local private investors relied on the guidelines from the Master Plan that recommended the regime of permanent reconstruction [6]. It implied a very radical mean of transforming existing urban fabric through replacement of single-family and complex housing units with multi-family buildings, with the aim of improving the housing quality, increasing population density and recycling inadequately utilized urban land [7].
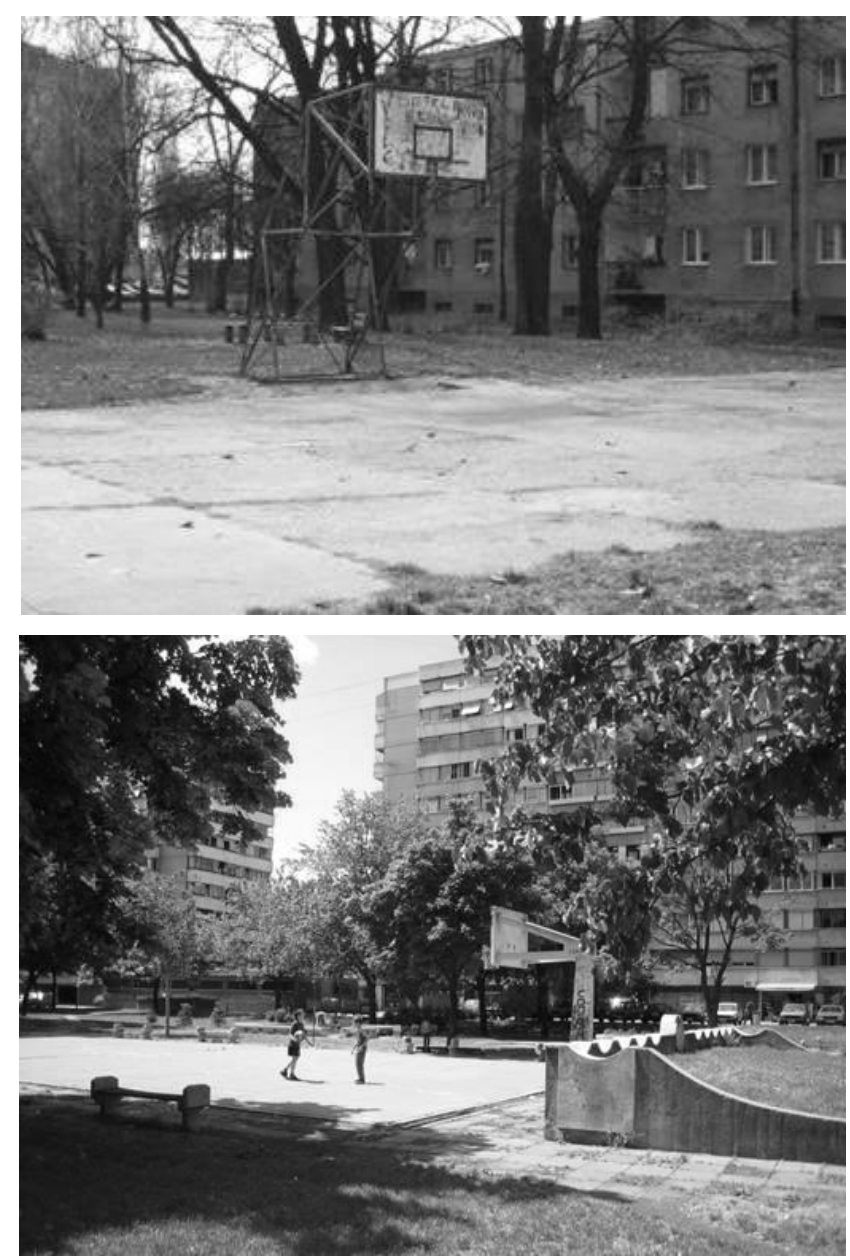

Figure 1: Open spaces within urban neighbours built during 1960 s and 1970s in Novi Sad: (left image) "Detelinara" neighbourhood; (right image) "Liman 2" neighbourhood

The transformation of residential neighbourhoods in Novi Sad under this regime began at the end of the 1990s, resulting not only in a change of housing typology and population density, but also in a decrease in size and quality of public spaces (Figure 2 ). They remained forgotten in between newly built structures and lost one of their primal functions - to serve as focal points of neighbourhood's everyday life.

A great impulse for attracting private investments in housing construction was a change in planning documentation for some residential areas, which provided the opportunity for various interpretations of its guidelines. To illustrate, the regulatory plan for the Grbavica neighbourhood from 1999 stated that remaining single-family houses could be replaced with new multi-family ones up to five floors high, with the aim of forming closed urban blocks within the existing street network. The newly erected residential buildings became a by-product of "achieving a one square meter more" slogan of the private investors and consisted of small housing units, such as studios and single-room flats that could easily be sold or rented. Apart from the use of poor quality materials and architecture distorted in the abundance 
of colours and randomly organized decorations, this new trend in residential construction also neglected the principles of housing quality from the aspect of interaction between a building and its surroundings.

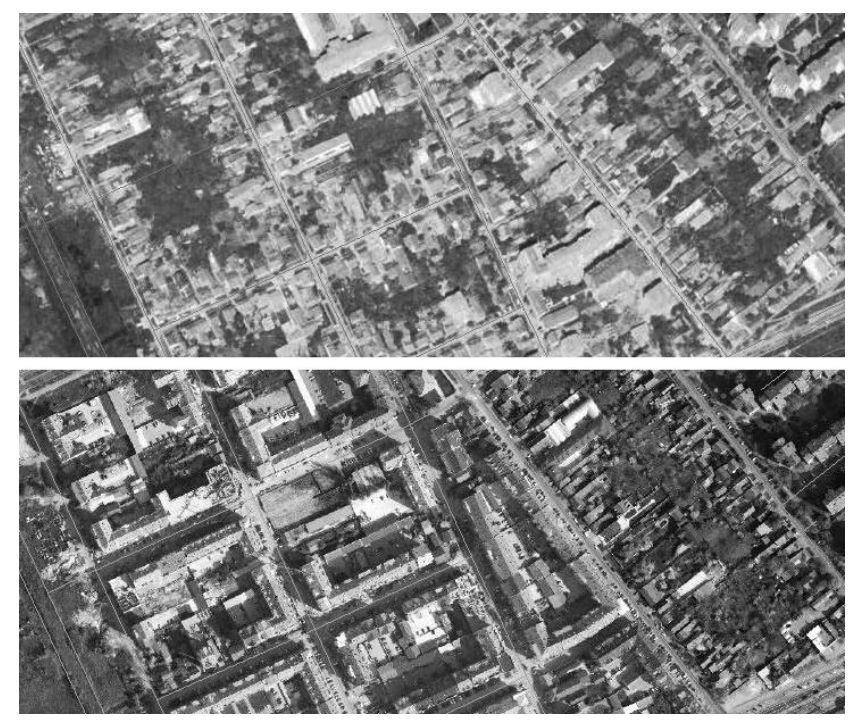

Figure 2: Urban morphology in Novi Sad: (above image) the beginning of 1990s; (below image) today

Public spaces inherited from the 20th century's urban matrix do not correspond to the newly built urban fabric with their size, structure and organization. They are fragmented within the blocks and used almost exclusively for parking. Disorder of public spaces, in combination with inadequate blocks' morphology, resulted in a lack of their true ambient value, especially from the aspect of children's needs (Figure 3).

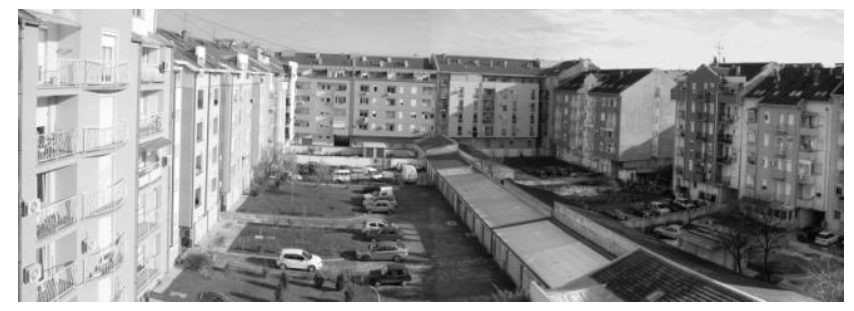

Figure 3: Inner-courtyard of an urban block in "New Detelinara" neighbourhood, built at the beginning of the $21^{\text {st }}$ century, without public spaces for children's play

\section{Importance of Public Spaces for Children}

Children's play is one of the most important activities for their growing up and development. Certain fields of psychology and pedagogy regard it as a basic type of children's activity, as it reflects the whole neuro-physical state of a child and its biological and physical needs [8]. According to Gross, children's play originates from their natural needs and impulses, thus having a biological significance - it prepares them for life, since creativity sharpens intelligence and, psychologically speaking, gives pleasure. Children develop their psychophysical characteristics of personality and exercise socialisation [9]. While playing, they also experience different emotional reactions to the environment; they explore it, understand it, create special relations and bond with it.

Children are one of the most frequent usergroups of public spaces. Complex and artificial environment in which they grow up offers them fewer opportunities to discover the world around with their own senses. "Cramped quarters for moving and meeting with other children have as a result specific isolation from real life, intensified by an effect of hypnovision and other mediums of artificial information. In this way, children are deprived of their own possibilities for their own authentic experience which is important in their development" [10].

In a contemporary world, architects and urban planners have an important role in creating spaces for children - in this process; they have to consider educational elements and different activities that stimulate children's imagination and their exploring spirit [11]. The aim of architectural design is to provide children with public spaces where they can develop social behaviour and, at the same time, overcome the sense of loneliness by spending time outside rather than at home. Due to this reason, children's needs, especially in urban environments, have to be taken into account while designing public spaces that could encourage proper psychophysical development and allow children to express themselves as individuals in their communities.

\section{Design Issues for Playgrounds}

Due to inadequately planned urban transformations, conducted during the post-socialist period, Novi Sad is nowadays faced with a lack of public spaces for children within newly built neighbourhoods. At the same time, the majority of inherited ones within large housing estates erected during the socialist period are devastated, run-down or even ruined. Insufficiently and unclearly defined planning regulations are the main reason why these spaces are of minimal capacity or do not even exist in some neighbourhoods. On the other hand, when incorporated, they are often uninspiring and unexciting, with prefabricated elements used all the same around the city, which brings us to the problem of inadequate design standards. Children should have much more places for interaction with surrounding 
environment, which can provide them with various opportunities to explore and interact with the world around. Apart from these problems, there are also issues regarding some basic functional features of public spaces for children, which need to be reconsidered during the design process. This process cannot only include decisions about choosing appropriate equipment, but many other considerations, such as overall site design, materials, paving, greenery, safety issues, etc. Unfortunately, most of newly built playgrounds equipment is only built on the site that is not holistically designed, that results in less attractiveness among children and their seeking for some other inspiring places for play. At the same time, some older playgrounds and sport grounds are interesting for children, due to their good incorporation in urban neighbourhood and presence of other important elements, such as urban furniture, greenery, etc. (Figure 3). The problem of public playgrounds is even bigger if we consider the fact that kindergarten and school playgrounds are private and enclosed areas, and therefore their use is limited to children who attend those institutions and almost exclusively during working hours.

While designing public spaces for children, it is also necessary to keep in mind different age groups of users (according to children's psychosocial needs), since there is a functional differentiation regarding their specific psychophysical needs, particularly in terms of contents and safety. The types of public spaces for children's play are:

- Playgrounds with different elements/ equipment for play, usually located near children's institutions and within residential areas, which offer, but also impose certain kinds of physical activities;

- Green areas in open or semi-open urban blocks, which enable children to imagine and create games by their own rules;

- Sports fields - places for recreation and various sport activities, usually located near schools and in urban clusters.

Public spaces for children should be located in the vicinity of multi-family buildings and accessible to all potential users, especially disabled children. Playgrounds need to be spacious in order to allow various activities, with proper amount of the natura light, wind protection, adequate vegetation, and presence of water, sanitary facilities, urban furniture and some storage space. The selection of used elements for play is also of great importance - they should have a challenging role in children's play, must be safe, of high quality, and appropriate in the sense of design, dimensions and used materials, but also adaptable and flexible to changes in children's needs. Essential role of architects and urban planners is to design public spaces where children can perform different activities. They need to make an effort to create environment with everyday challenges suitable for children of different ages, genders and development levels. However, in order to upgrade this process, the design team should take in consideration the way children see and experience the world around them.
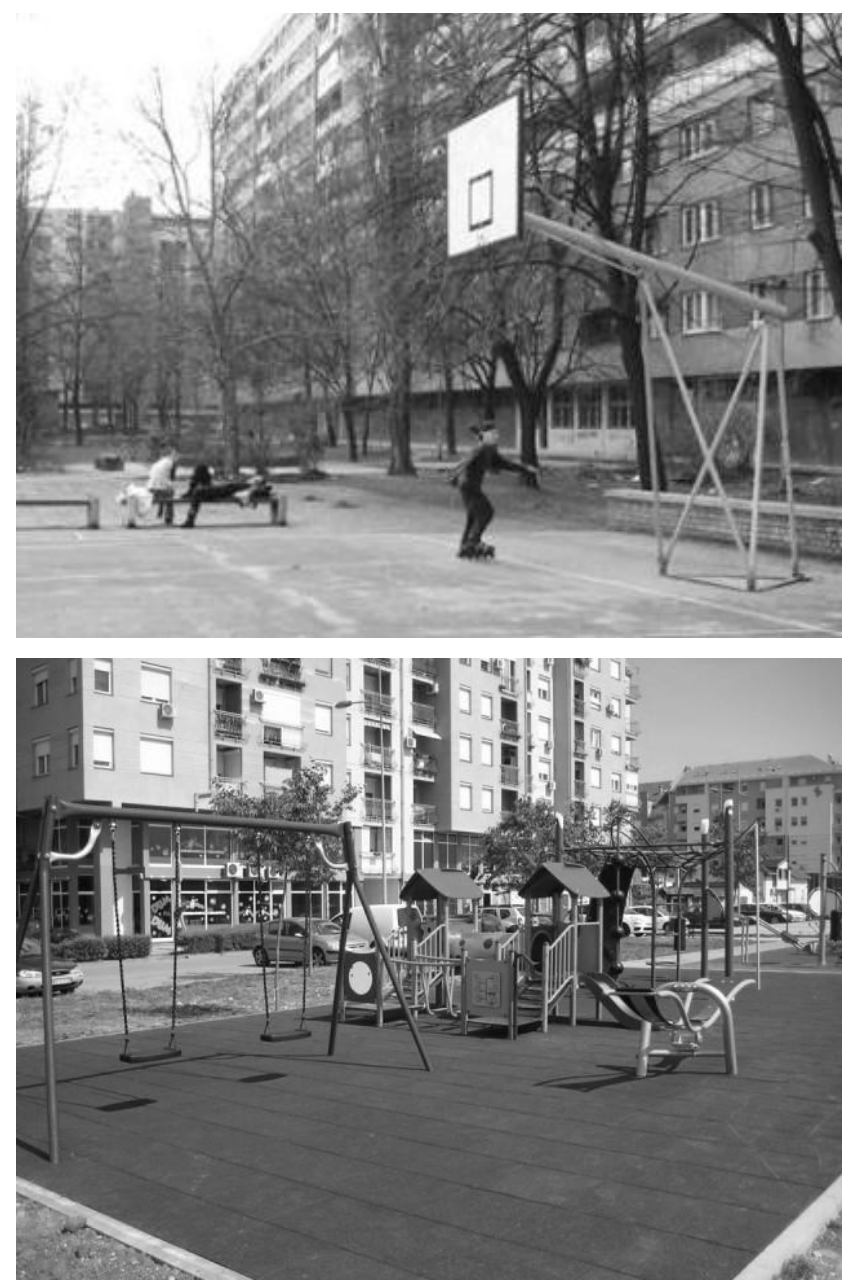

Figure 4: Playgrounds: (top image) in a socialist neighbourhood, (bottom image) in a transformed urban neighbourhood

From children's perspective, space is a series of different activities connected to a particular place, but it can only be identified after certain experiences create children's own image of that specific place. Small and poorly designed public spaces around urban neighbourhoods transformed in a post socialist period could hardly be recognised as attractive and inspiring for children. It is obvious that good overall design of urban neighbourhoods, with wide green areas, sport fields and playground, can offer spaces for various play activities, which could be easily transformed and redesigned in line with contemporary standards and in the sense of sustainable design (Figure 4). During the last ten years, public playgrounds in Novi Sad have been built in some areas, some were renewed, but some of them are still in a very bad condition or completely demolished. Unfortunately some newly built playgrounds are not 
sufficiently used due to their poor design and some have even been demolished. Although there are no statistical data about number of public playgrounds, the Public Enterprise for City Construction and Development of Novi Sad, designs and redisignes approximately ten various public spaces for play activities each year, depending on financial and spatial possibilities.
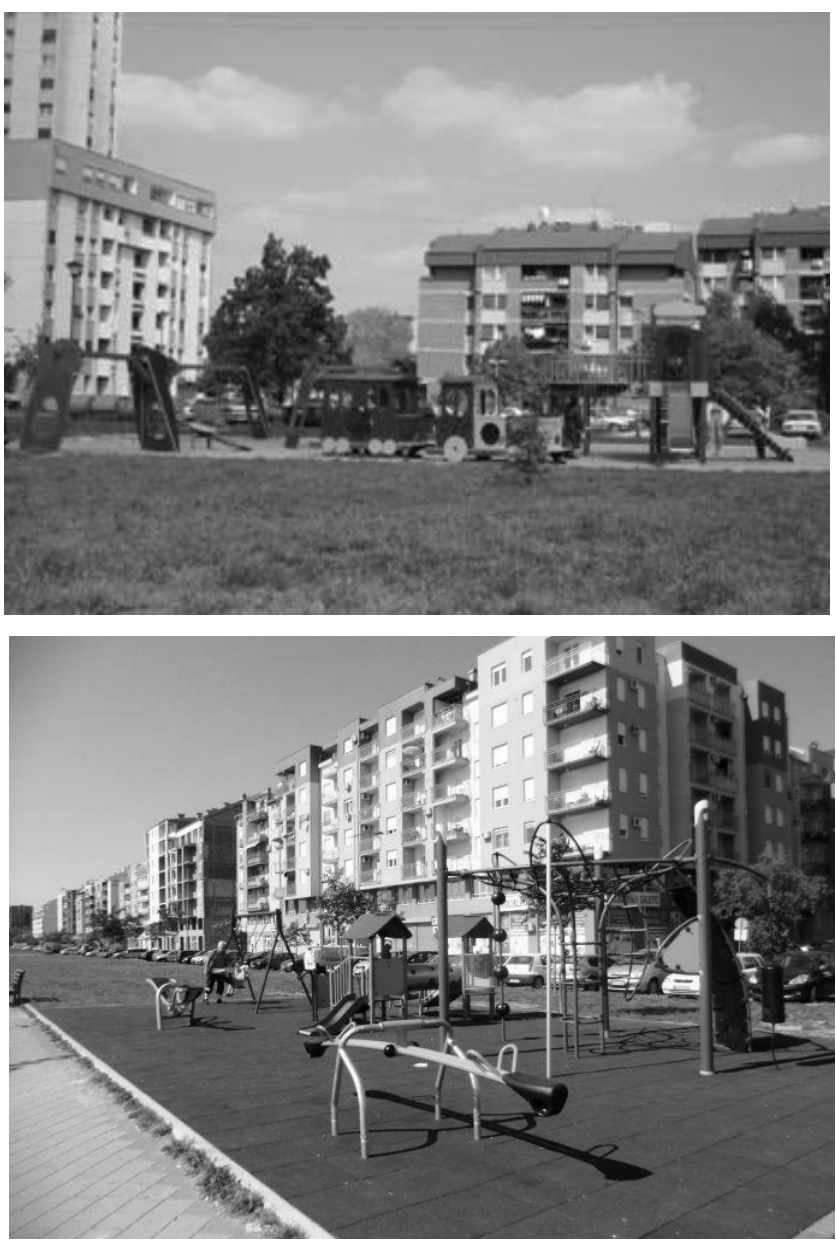

Figure 5: Playgrounds: (left image) refurbished one in a socialist neighbourhood "Liman 2"; (right image) along the boulevard in a transformed urban neighbourhood "New Detelinara"

In conclusion, the socialist legacy of architectural design and urban planning strategies in terms of housing was altered by the new post-socialist patterns. Residential construction became insufficiently regulated and predominantly profitdriven, which resulted in a disregard of the value public spaces need to have. In that sense, the biggest loss was the one of the children living in transformed city neighbourhoods. Upon analysing public spaces for children in these districts, it can be concluded that there is a significant shortage of attractive places for gathering, play and other leisure activities. It also seems that architects and urban planners did not pay much attention to children's needs. In addition, most of the playgrounds are poorly looked after or even ruined, which makes them extremely unsafe.
Therefore, all institutions in charge should have their own role in different actions for preservation and revitalisation of existing public spaces for children. Even though children need freedom to create their own spaces, guided by their own imagination, the city should, at the same time, provide them with attractive, inspiring, carefully planned and designed according to the highest standards.

One of the most important sentiments during growing up is the sense of belonging to a certain space, and discovery and exploration of selfexpression and individualism. The duty of an architect is to design and provide spaces for children, which will be accepted as the environment where they will grow up and be able to express their individualism. Local authorities and relevant experts should have equally important roles in this process. The distribution of public spaces, their proportions and dimensions, programs and contents, should all be planned with the aim to create harmony between spaces and their users, making the whole process of socialization more successful and intensive. The city has an obligation to pay attention to children's needs and make an effort to create best possible places for their future.

\section{References}

1. Tosics I. City development in Central and Eastern Europe since 1990: The impacts of internal forces. In Hamilton FI, Dimitrovska Andrews K, Pichler-Milanović N, eds. Transformation of cities in Central and Eastern Europe: Towards globalization. Tokyo: United Nations University Press, 2005:pp. 44-78.

2. Pichler-Milanović N, Dimitrovska Andrews K. Conclusions, in Hamilton FI, Dimitrovska Andrews K, Pichler-Milanović N, eds. Transformation of cities in Central and Eastern Europe: Towards globalization. Tokyo: United Nations University Press, 2005: pp. 465-487.

3. Bobic M. Grad izmedju arene i scene. Urbani spektakl, Beograd: Clio, 2000.

4. Čaldarović O, Šarinić J. First signs of gentrification? Urban regeneration in the transitional society: the case of Croatia, Sociologija i proctor. 2008; 46(3-4):369-381.

5. Pušić Lj. Grad bez lica. Novi Sad: Mediterran Publishing, 2009.

6. Nedučin $D$, Carić $O$, Kubet $V$. Influences of gentrification on identity shift of an urban fragment: A case study. Spatium. 2009;21:66-75.

http://dx.doi.org/10.2298/SPAT0921066N

7. Master Plan of the City of Novi Sad until 2005. Novi Sad: Skupština Grada Novog Sada, 1985.

8. Maletic S. Značaj decje igre i decja igralista. Beograd: Partizan, 1970.

9. Dobson F. Getting Serious About Play, A review of children's play, 2005. http://www.culture.gov.uk

10. Kamenov E. Intelektualno vaspitanje kroz igru. Beograd: Zavod za udzbenike i nastavna sredstva, Sarajevo: Svjetlost OOUR Zavod za udzbenike i nastavna sredstva, 1989.

11. Heintz D. D'espaces et d'enfants. T \& a, n.473, Dossier: Petite enfance, Commission Washington, DC 20207, 2004:pp. 19-27. 